\title{
Teaching in culturally and linguistically diverse classrooms: Turkish EFL instructors' experience
}

\author{
Rana Y1ldırım * \\ Cukurova Uiversity, ELT Department, Adana, 01130, Turkey
}

\section{APA Citation:}

Yıldırım, R. (2019). Teaching in culturally and linguistically diverse classrooms: Turkish EFL instructors' experience. Journal of Language and Linguistic Studies, 15(3), 1155-1170.

Submission Date:09/02/2019

Acceptance Date:23/09/2019

\begin{abstract}
This study investigates Turkish EFL instructors' perceptions regarding their readiness for and potential challenges that they face in classrooms with students from diverse cultural and linguistic backgrounds. Using both quantitative and qualitative methods of inquiry, data were collected by utilizing the Multicultural Teaching Competency Scale (MTCS) (Spanierman, Oh, Heppner, Neville, Mobley, Wright, Dillon, \& Navarro, 2011) and semi-structured interviews. The findings acquired from the scale revealed that the majority of the participating instructors perceived themselves as competent, yet further inquiry through the interviews indicated that they feel challenged while meeting the academic and linguistic needs of diverse group of students as they lack relevant formal training. The study calls for an urgent need to make provision for training programs designed to increase instructors' awareness, knowledge and skills to work effectively in culturally and linguistically diverse education contexts.**

(C) 2019 JLLS and the Authors - Published by JLLS.
\end{abstract}

Keywords: Multicultural education; teacher competency; multicultural teaching competency; language teaching; EFL

\section{Introduction}

By the numbers released by the United Nations Refugee Agency (UNHCR), as of 2019, an unprecedented 70.8 million people around the world have been forced from home. Among them, there are nearly 25.9 million refugees, and over half of them are under the age of 18 (Retrieved on August, 2019). By the same numbers, Turkey; for the fifth consecutive year, is hosting the largest number of refugees with 3.7 million people. Akin to UNHCR statistics, Turkish Ministry of Interior (2019) reports the number is slightly lower with 3.643 .870 registered refugees, and $44.7 \%$ of them are children under the age of 18. As affirmed by the Universal Declaration of Human Rights, Article 26 (1948), education [free from ethnic, racial or linguistic background] is a basic human right. Given the fact that a high number of people from different ethnic, racial and linguistic backgrounds are coming together at schools,

\footnotetext{
* Corresponding author. Tel.: +0-000-000-0000

E-mail address: ranayi@gmail.com

** For the purpose of clarity and easiness, the phrases "multicultural and multilingual contexts" and "contexts with learners from diverse cultural and linguistic backgrounds" are used interchangeably in this paper.
} 
it is not only essential, but also inevitable for teachers to acquire and build up a multicultural competence, in addition to area competence and pedagogical competence since education is a need that should be provided for all learners equally.

To make matters more interesting, while teachers teaching other disciplines can avoid the issue of culture and multiculturalism to a degree, language teachers and instructors cannot afford such luxury as the job itself is teaching a language; thus a culture. When such is the case, ignoring the native cultures and languages of the learners is simply unproductive, even when the humanitarian aspects of it are to be ignored for the sake of argument. Though it is every the teacher's task to be respectful and accommodating to the culture of the learners (or any culture for that matter), given the higher readiness and sensitivity of the learners at university level, the matter of building up multicultural competence is even more vital for language instructors at universities. Given the lack of formal training opportunities for language instructors during degree programs, the study aimed to assess where the EFL instructors stand, and how they cope with potential issues stemming from multicultural and multilingual contexts ${ }^{1}$ in which they are teaching.

\subsection{Literature review}

\subsubsection{Multiculturalism}

Multiculturalism is defined by the Oxford Dictionaries (2018) as the presence of, or support for the presence of, several distinct cultural or ethnic groups within a society. As the dictionary definition of multiculturalism suggests, it is crucial to define what culture is prior to defining what multiculturalism means and how it affects individuals, as it is impossible to define what one is without defining what the other is. Culture is defined as "the set of distinctive spiritual, material, intellectual and emotional features of society or a social group, and that it encompasses, in addition to art and literature, lifestyles, ways of living together, value systems, traditions and beliefs" by UNESCO Universal Declaration on Cultural Diversity (2001, p. 3). Matsumoto and Juang (2007) refine the concept as "a unique meaning and information system, shared by a group and transmitted across generations, that allows the group to meet basic needs of survival, pursue well-being, and derive meaning from life."

Though it is relatively easy to come up with a definition for multiculturalism, or grasp the basic premise of the term based on the definition of culture, the matter of multiculturalism seems to be complicated when it comes to practice. Modood $(2015, \mathrm{p} .1)$ defines multiculturalism as "a mode of integration that can be contrasted with other modes, such as assimilation, individualist integration, and cosmopolitanism"; then elaborates, "like the others, [multiculturalism] is based on the core democratic values of liberty, equality, and fraternity or unity." Defining multiculturalism as a perspective on human life rather than a political doctrine or a philosophical theory, Parekh (2006) states that a culture's relation to itself shapes, and is in turn shaped by its relation to the others; and their internal and external pluralities presuppose and reinforce each other. In other words, without contrasting one's own values to the others, it is impossible to determine where one stands.

\subsubsection{Multiculturalism in education}

Banks \& Banks (2001) define multiculturalist education as an idea, an educational reform movement, and a process whose major goal is to change the structure of educational institutions so that male and female students, exceptional students, and students who are members of diverse racial, ethnic, linguistic, and cultural groups will have an equal chance to achieve academically in school. In alignment with and on expansion of Banks \& Banks (2001), Nieto (2000) provides one of the most comprehensive definitions of multiculturalism in education as;

Multicultural education is a process of comprehensive school reform and basic education for all students. It challenges and rejects racism and other forms of discrimination in schools and 
society and accepts and affirms the pluralism (ethnic, racial, linguistic, religious, economic, and gender among others) that students, their communities, and teachers reflect. Multicultural education permeates the schools' curriculum and instructional strategies, as well as the interactions among teachers, students and families, and the very way that schools conceptualize the nature of teaching and learning. Because it uses critical pedagogy as its underlying philosophy and focuses on knowledge, reflection, and action as the basis for social change, multicultural education promotes democratic principles of social justice (p. 305).

Noting many school and university practitioners have a limited conception of multicultural education; i.e. primarily as curriculum reform to include diverse content, Banks (1993, p. 5) elaborates that the changes need to extend to the (a) teaching materials; (b) teaching and learning styles; (c) the attitudes and perceptions and behaviors of teachers and administrators; (d) and the goals, norms and culture of the school.

\subsubsection{Racial and Ethnic Identity Theories and their Educational Implications}

Quintana (1998) (cited in Quintana, 2007) briefly describes race and racial differences, and ethnicity and ethnic differences as concepts "based on perceived differences or, more technically, as the social distance between different groups from a developmental perspective" (p.259).

According to Chavez and Guido-DiBrito (1999), the individuals from the mainstream, or dominant, culture manifest ethnic and racial identity in mostly unconscious ways through their behaviors, values, beliefs, and assumptions. For the members of the mainstream culture, ethnicity is usually invisible and unconscious, because societal norms have been constructed around their racial, ethnic, and cultural frameworks, values and priorities, and then referred as the standard rather than "ethnic identity". Thus, individuals with different societal norms and values are likely to feel shame or disconnection toward their own ethnic identity if positive ethnic group messages and support are not apparent, or available to counteract negative public messages. As racial and ethnic identity can affect the relationship with learning that individuals have in their learning environments, it is important to understand the culturally constructed nature of educational environments, and to develop an awareness, since minority and international adult learners face difficulties when they attempt to negotiate learning environments that have been constructed within an ethnic base of values, behaviors, beliefs and ways of doing things that are different from their own.

\subsubsection{Culturally Responsive Pedagogy}

Gay (2002) defines culturally responsive teaching, which Banks (1993, p.6) calls "Equity Pedagogy", as using the cultural characteristics, experiences, and perspectives of ethnically diverse students as conduits for teaching them more effectively. Along the same lines, Lynch (2011) defines culturally responsive pedagogy as a student-centered approach to teaching in which the students' unique cultural strength is identified and nurtured to promote student achievement and a sense of well-being about the student's cultural place in the world. He divides culturally responsive pedagogy to three dimensions: the institutional dimension, the personal dimension and the instructional dimension, while Gay (2002, p. 106) states that the knowledge, attitudes and skills needed for culturally responsive pedagogy have five essential elements, which are;

a. Developing a knowledge base about cultural diversity

b. Including ethnic and cultural diversity content in the curriculum (which requires the assistance of the institutions rather than teachers striving on their own.)

c. Demonstrating caring and building learning communities

d. Communicating with ethnically diverse students

e. Responding to ethnic diversity in the delivery of instruction. 
Spanierman et al. (2011) whose MTCS was utilized during the data collection of this study describe multicultural teaching competence as an iterative process in which teachers continuously

(a) explore their attitudes and beliefs about multicultural issues,

(b) increase their understanding of specific populations, and

(c) examine the impact this awareness and knowledge has on what and how they teach as well as how they interact with students and their families.

Elaborating more, Spanierman et al. (2011) emphasize three dimensions to multicultural teaching competence, namely awareness, knowledge, and skills. Awareness dimension comprises the acknowledgment of the culture, cultural biases and attitudes, and the needs to create a culturally accommodating environment for all the students. Knowledge dimension comprises teachers' and instructors' knowledge of culturally responsive pedagogy and instructional strategies related to diverse populations, major socio-historical and current socio-political realities, and cultural dynamics in relation to their effect of the group dynamics. And finally, the skill dimension is defined as teachers' and instructors' ability to actively select, develop, implement, and evaluate strategies that facilitate the academic achievement and personal development of all students; select and implement culturally sensitive behavioral management strategies and interventions; and participate in ongoing review and evaluation of school policies, procedures, and practices with regard to cultural responsiveness.

\subsection{Research questions}

The following research questions guided the study:

1. What is the perception of Turkish EFL instructors regarding their readiness to teach learners from diverse cultural and linguistic backgrounds?

2. How do the instructors assess their multicultural competence with specific reference to their multicultural knowledge and multicultural skills?

\section{Method}

\subsection{Research design and data collection tools}

In line with its purpose, the study adopted a mixed method approach where data were collected and analyzed using both quantitative and qualitative methods (Fraenkel, Wallen \& Hyun, 2012). Mixed method research, which is dubbed as third-wave research movement, moves past the paradigm wars by offering a logical and practical alternative (Johnson \& Onwuegbuzie, 2004) thus, enabling us to compare quantitative and qualitative data as well as allowing for two sets of data to support one another for reliability purposes. Quantitative data were obtained through the administration of the MTCS (Spanierman et.al, 2011), which is a two-dimensional, 16 item scale with a demographics section. On the demographic portion of the scale, the participants answered questions on their age, gender, ethnic background, educational background, teaching experience, teaching experience in multicultural and multilingual settings, whether they received any formal training on multicultural teaching practices, and how they attained their current multicultural competence. Then, the participants were provided with 16 statements on their multicultural teaching skill and multicultural knowledge, and asked to assess themselves on a 6 point Likert scale (1=Strongly Disagree, 2=Moderately Disagree, $3=$ Slightly Disagree, 4=Slightly Agree, 5=Moderately Agree, 6=Strongly Agree). After receiving Dr. Lisa Spanierman's permission to use the MTCS, the scale was administered online. 
For the qualitative portion of the research, a set of interview questions that borrow the terminology of the scale was first designed. However, upon piloting the interview, it was observed that the participants were not comfortable with answering direct questions on their theoretical knowledge. Thus, the interview was redesigned in a manner that was aligned with the statements in the MTCS focusing on the participants' multicultural knowledge and skills yet were more indirect as for the participants to share their personal experiences and perspectives. Therefore, the final interview questions are as follows;

1. Do you ever have issues because you have a student/students from diverse cultures and languages in your classroom? If yes, could you elaborate?

2. Do you think the educational issues are dependent on the cultural and linguistic background of the learner? Do learners from a culture different from your local culture have different issues in language learning from those of Turkish learners? If yes, could you elaborate?

3. In your own experience, what kind of methodology is best suited to the needs of a multicultural and multilingual classroom setting?

4. Have you ever needed to adapt or modify your material due to the multicultural and multilingual setting of your classes? If yes, why/how? If no, why not?

5. Do you think the learner's cultural and linguistic identity plays a role in their language learning process? If so, how?

6. Do you think your own cultural background has an effect on your teaching?

7. Do you promote cultural and linguistic diversity in your classrooms? If so, why/how? If no, why not?

Two of the interviews were conducted face-to-face. Due to inaccessibility, four were conducted through Skype. Five were recorded with the consent of the participants. For the remaining one, detailed notes were taken. All the interviews were held in English and each lasted about an hour.

\subsection{Sampling}

Although issues related to teaching in diverse classrooms are of concern for all language teachers on some level, this study focused on language instructors at preparatory schools, since they were considered to be more sensitive to the issues of linguistic and cultural diversity in their classes as their student body comprises of young adults who are bound to have a higher awareness of diversity and ethnic identities (Erikson, 1968; Phinney\&Alipuria, 1987). Keeping this in mind, purposive sampling (Chein, 1981) was adopted to reach out data-rich participants to delve directly into the objective of the study.

Having reached the administration of the School of Foreign Languages of a State University, 24 instructors who were teaching in diverse classrooms at the time of the data collection were invited to participate by email. In order to reach more participants, the snowball sampling (Patton, 2002) was followed to prepare a list of instructors that the researcher personally knew to be working in diverse classrooms. Those instructors were reached via email and social media platforms. They were also asked to forward the URL to other instructors they know to be information-rich. Through a combination of purposive and snowball sampling, the MTCS was administered and responses from 48 instructors working at various state universities were collected.

To collect data through the interviews, all the participants who responded to the scale were invited to participate in the interviews on a voluntary basis. Six participants agreed to take part in the interviews. Of the six participants, two hold Master's degrees in English Language Teaching, two are English Literature graduates with teaching certificates, and the remaining two hold BA degree in English Language Teaching graduates. All of them were, at the time of the study, teaching for more than five years. 


\subsection{Data analysis}

The instructors' responses to Likert-type questions in the MTCS were analyzed through the descriptive statistics extension of SPSS software since descriptive statistics enables the researchers to present the data in a more meaningful way allowing simpler interpretation of the data (Çokluk, Şekercioğlu \& Büyüköztürk, 2014). Percentages and mean scores were calculated in determining the instructors' assessment of their multicultural knowledge and skill and interpreting the data. The interviews were transcribed verbatim, and the transcripts were subjected to content analysis to make sense of the raw data (Miles and Huberman, 1994). For validity and reliability purposes, the researcher worked with another colleague during the analysis. The transcriptions were separately coded and emerging themes were identified. In case of disagreement, the emergent themes were, then, compared and re-coded until a consensus was reached.

\section{Findings and Discussion}

This section first presents the findings acquired from quantitative data analysis, it then reports on the findings obtained from the qualitative data analysis in a complementary fashion.

\subsection{Findings acquired from the MTCS}

On the demographic portion of the MTCS, the participants answered questions on their age, gender, ethnic background, educational background, teaching experience, teaching experience in multicultural and multilingual settings, whether they received any formal training on multicultural teaching practices, and how they attained their current multicultural competence.

Of the 48 participants, whose ages vary between 26 and $57,68.1 \%$ is female and $27.7 \%$ are male. In terms of educational background, 70.2\% are English Language Teaching graduates, $16.7 \%$ are English Language Literature graduates, $4.2 \%$ are Translation and Interpretation graduates, and the remaining 8.4\% are English Linguistics graduates.

When asked to disclose their teaching experience, $43.80 \%$ of the respondents noted they have more than 10 years of hands on experience in language classes. (25\% has eight to ten years of experience, $22.90 \%$ has four to seven years, and $8.30 \%$ has one to three years of teaching experience.) However, when queried about their teaching experience in diverse settings, the rates have dropped. $10.4 \%$ of the participants have less than a year of teaching experience in diverse settings. $6.3 \%$ has a year of experience; $20.8 \%$ has two to three years; $25 \%$ has three to five years and $37.5 \%$ has more than five years of teaching experience in such settings.

Following the questions on their teaching experience, the participants shared whether they received any training focusing on teaching learners from diverse cultural and linguistic backgrounds. While, an overwhelming majority of the participants $(75 \%)$ stated that they received no formal training, $65.5 \%$ of all the participants, nonetheless, replied to the following open-ended question asking them to elaborate on the nature of the multiculturalism training they received. Of the 31 participants, $60.6 \%$ stated they attended conferences and another $33.3 \%$ said that they participated in workshops. There were participants who reported on other options including cultural competency trainings (12.1\%), learning on the job (3\%), following literature on the issue (3\%, and becoming involved in EU projects on cultural competence $(3 \%)$. 


\subsubsection{The multicultural knowledge}

The first dimension of the MTCS focuses on is the multicultural knowledge of the participants. Unlike the multicultural skill portion of the scale, where the focus is on the actions the participants take in the class and with their diverse student body, this first dimension is of more theoretical nature and queries into the realm of espoused theories. Table 1 shows the participating EFL instructors' assessment of their Multicultural Knowledge.

Table 1. EFL Instructors' Assessment of their Multicultural Knowledge.

\begin{tabular}{|c|c|c|c|c|c|c|c|c|}
\hline Multicultural Knowledge & 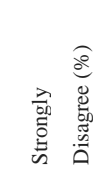 & 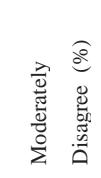 & 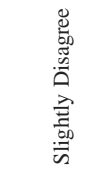 & 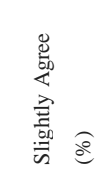 & 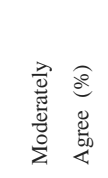 & 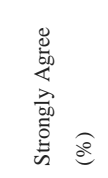 & $\overline{\mathrm{x}}$ & $\operatorname{std}(X)$ \\
\hline $\begin{array}{l}\text { 2. I understand the various communication } \\
\text { styles among different racial and ethnic } \\
\text { minority students in my classroom. }\end{array}$ & 2.1 & - & - & 18.7 & 47.9 & 31.3 & 5.04 & 0.922 \\
\hline $\begin{array}{l}\text { 4. I have a clear understanding of culturally } \\
\text { responsive pedagogy. }\end{array}$ & 2.1 & 8.3 & 12.5 & 27.1 & 33.3 & 16.7 & 4.31 & 1.257 \\
\hline $\begin{array}{l}\text { 7. I am knowledgeable about racial and } \\
\text { ethnic identity theories. }\end{array}$ & 6.3 & 12.5 & 14.6 & 35.4 & 22.9 & 8.3 & 3.81 & 1.331 \\
\hline $\begin{array}{l}\text { 9. I am knowledgeable of how historical } \\
\text { experiences of various racial and ethnic } \\
\text { minority groups may affect students' } \\
\text { learning. }\end{array}$ & 6.3 & 8.3 & 10.4 & 20.8 & 33.3 & 20.9 & 4.29 & 1.458 \\
\hline $\begin{array}{l}\text { 11. I am knowledgeable about the particular } \\
\text { teaching strategies that affirm the racial and } \\
\text { ethnic identities of all students. }\end{array}$ & 6.3 & 12.5 & 8.3 & 43.8 & 18.8 & 10.3 & 3.88 & 1.331 \\
\hline $\begin{array}{l}\text { 14. I am knowledgeable about the various } \\
\text { community resources within the city that I } \\
\text { teach. }\end{array}$ & 10.3 & 16.7 & 16.7 & 31.3 & 20.8 & 4.2 & 3.48 & 1.384 \\
\hline
\end{tabular}

Even though $75 \%$ of the participants stated they did not receive any formal training focusing on multiculturalism, it can be seen in Table 1 that the participants tend to assess themselves on the positive end of the scale when inquired about their multicultural knowledge. It is seen, when the responses given to Slightly Agree, Moderately agree, and Strongly Agree are taken into account, that the rate of the positive responses makes up $97.9 \%$ of all answers for item $2,77.1 \%$ for item $4,66.6 \%$ for item $7,75 \%$ for item $9,72,9 \%$ for item 11 and $56.3 \%$ for item 14 . The relatively low positive response rate for item 14 , utilizing the community resources, can be explained by the comment that one of the participants left at the end of the MTCS:

\section{Excerpt 1}

For item 14, I'm not sure there are organizations to support certain groups in the society. This doesn't sound Turkish to me.

\subsubsection{The multicultural skill}

Though multicultural competence is stated to be three-dimensional by the scale developers (Spanierman et. al., 2011), the MTCS itself is comprised of skill and knowledge dimensions only; leaving us to derive our own conclusions regarding multicultural awareness of the participants as the level of skill and knowledge provides an idea regarding the awareness of the participants. 
Table 2. EFL Instructors’ Assessment of their Multicultural Skill.

\begin{tabular}{|c|c|c|c|c|c|c|c|c|}
\hline Multicultural Skill & 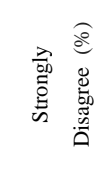 & 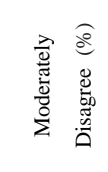 & 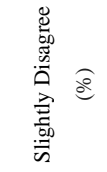 & 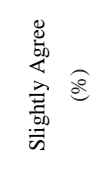 & 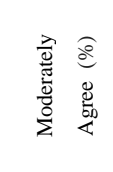 & 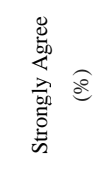 & $\overline{\mathrm{x}}$ & $\operatorname{std}(X)$ \\
\hline $\begin{array}{l}\text { 1. I plan many activities to celebrate diverse } \\
\text { cultural practices in my classroom. }\end{array}$ & 2.1 & 2.1 & 10.4 & 33.3 & 41.7 & 10.4 & 4.42 & 1.028 \\
\hline $\begin{array}{l}\text { 3. I consult regularly with other teachers or } \\
\text { administrators to help me understand } \\
\text { multicultural issues related to instruction. }\end{array}$ & 4.2 & 18.7 & 6.3 & 37.5 & 25 & 8.3 & 3.85 & 1.337 \\
\hline $\begin{array}{l}\text { 5. I often include examples of the } \\
\text { experiences and perspectives of racial and } \\
\text { ethnic groups during my classroom lessons. }\end{array}$ & 4.1 & 6.3 & 2.1 & 22.9 & 41.7 & 22.9 & 4.60 & 1.284 \\
\hline $\begin{array}{l}\text { 6. I plan school events to increase students' } \\
\text { knowledge about cultural experiences of } \\
\text { various racial and ethnic groups. }\end{array}$ & 29.2 & 14.6 & 8.3 & 10.4 & 25 & 12.5 & 3.25 & 1.885 \\
\hline $\begin{array}{l}\text { 8. My curricula integrate topics and events } \\
\text { from racial and ethnic minority populations. }\end{array}$ & 10.4 & 10.4 & 18.8 & 39.6 & 18.8 & 2.1 & 3.52 & 1.271 \\
\hline $\begin{array}{l}\text { 10. I make changes within the general school } \\
\text { environment so racial and ethnic minority } \\
\text { students will have an equal opportunity for } \\
\text { success. }\end{array}$ & 12.5 & 10.4 & 8.3 & 35.4 & 20.8 & 12.5 & 3.79 & 1.529 \\
\hline $\begin{array}{l}\text { 12. I rarely examine the instructional } \\
\text { materials I use in the classroom for racial and } \\
\text { ethnic bias. }\end{array}$ & 20.8 & 27.1 & 18.8 & 16.7 & 10.4 & 6.2 & 2.88 & 1.511 \\
\hline $\begin{array}{l}\text { 13. I integrate the cultural values and } \\
\text { lifestyles of racial and ethnic minority } \\
\text { groups into my teaching. }\end{array}$ & - & 4.1 & - & 45.8 & 31.3 & 18.8 & 4.60 & 0.939 \\
\hline $\begin{array}{l}15 . \text { I often promote diversity by the } \\
\text { behaviours I exhibit. }\end{array}$ & 2.1 & - & - & 20.8 & 41.7 & 35.4 & 5.06 & 0.954 \\
\hline $\begin{array}{l}16 . \quad \text { I establish strong, supportive } \\
\text { relationships with racial and ethnic minority } \\
\text { parents. }\end{array}$ & 29.2 & 16.7 & 8.3 & 12.5 & 12.5 & 20.8 & 3.25 & 1.962 \\
\hline
\end{tabular}

Similar to the results of the Multicultural Knowledge dimension of the MTCS, the participants' assessment of their Multicultural Skill is considerably high. The positive responses (Slightly Agree to Strongly Agree) make up a considerable portion of the results. For item 1, of all the answers given, $85.4 \%$ are on the positive band. This suggests that an overwhelming majority of EFL instructors believes they plan many activities to celebrate diverse cultural practices in their classrooms. Concerning item 3, when the responses given to Slightly Agree, Moderately Agree, and Strongly Agree are taken into account, it is seen that another big majority of instructors (70.8\%) thinks they consult regularly with other teachers or administrators to help them understand multicultural issues related to instruction. Nonetheless, for the same item, when the responses given to Strongly Disagree, Moderately Disagree, and Slightly Disagree are considered, it is seen that $29.2 \%$ of the participants is not keen on cooperation. This finding is in contrast with what Gay (2002) and Bergeron (2008) suggest since they state the teachers need to cooperate and interact with supportive colleagues if they [the teachers] are to create diverse classroom contexts.

Other two items which received high positive responses from the participants are items 13 and 15. An overwhelming majority EFL instructors (95. 9\%) believes that they can integrate the cultural values and lifestyles of racial and ethnic minority groups into their teaching and another great majority (97. $9 \%$ ) reckons they often promote diversity by the behaviours they exhibit. Similarly, a further majority of EFL instructors (87. 5\%) views themselves as individuals who often include examples of the experiences and perspectives of racial and ethnic groups during their classroom lessons (Item 5). 
Furthermore, more than half of the participating EFL instructors (68. 8\%) believe they can make changes within the general school environment so racial and ethnic minority students will have an equal opportunity for success (Item 10) while another more than half (66.7\%) somewhat disagrees that they rarely examine the instructional materials they use in the classroom for racial and ethnic bias (Item 12).

Most participants through the comments that they wrote at the end of the scale stated that, item 16, establishing relationships with parents, is irrelevant in the teaching context of the instructors. Reflecting this irrelevance, it can be seen that this item has received one of the lowest scores on the scale. As for item 6 which is about planning school events to raise student awareness on the cultural experiences of ethnic and racial groups nearly half of the EFL instructors (47.9\%) stated they have this multicultural skill. As one of the participants commented in the interviews:

\section{Excerpt 2}

...the instructors can only control what the] do in their classrooms, which also has its limits.... taking adult university students on school trips or organizing events is beyond the capabilities of instructors.

Taking the EFL instructors' responses provided into account, it can be deduced that the instructors are content with the way they conduct their classes and are considering themselves to be highly skilled in terms of diverse classrooms when the results of items 16 and 6 are excluded.

\subsection{Findings acquired from the interviews}

In this section, the findings obtained from the semi-structured interviews are discussed in parallel with the scale results. In order to protect their privacy, the participants are given pseudonyms.

\subsubsection{Methodology and classroom practices}

In order to get a glimpse into the teaching practices of the participating instructors, in line with the scale items 1 (planning diversity promoting activities), 2 (understanding of the various communication styles employed by diverse groups), 4 (having a clear understanding of culturally responsive pedagogy), 5 (incorporating the experiences and perspectives of diverse students into the teaching practices), 11 (knowledge of teaching strategies that affirm the identities of all students) and 13 (integrating values and lifestyles of diverse students into teaching practices), the participants were asked in the interviews to describe their preferred methodology and current practice in multicultural and multilingual classes (Interview question: In your own experience, what kind of methodology is best suited to the needs of a multicultural and multilingual classroom setting?) Ayşe, who holds a Master's Degree in English Language Teaching, noted the importance of an intercultural perspective during instruction, and stated

\section{Excerpt 3}

Rather than focusing on a stereotyped native speaker culture, we need to integrate as many different cultures as possible into our teaching so that students with different cultures could also find something from their own culture and connect more with English language.

Though they have not described this ideal as "culturally responsive pedagogy", the remaining participants (Betül, Cansu, Deniz, Elif and Fatma) all noted that an egalitarian methodology, where diverse students' not being able to speak the dominant language is an asset rather than an obstacle, is the most suitable methodology for diverse classrooms. However, they all stressed that this idealized version may not always be possible to follow due to an unspoken pressure from the majority groups [Turkish speaking students] in the classes.

In this idealized version, the participants state that they conduct the classes entirely in the target language, and the presence of the minorities will lead to increased production from both (native students and the students of diverse backgrounds) groups. Nonetheless, it is noted, Turkish students are more 
testing-oriented in their approach to the language learning, and are not very interested in the communicative aspect of the language; thus, forcing the instructor to prepare them for the exams by following a more didactic and rigid approach. Betül, an English Language and Literature graduate with a Master's and $\mathrm{PhD}$ in the same area, describes the situation as in the following:

\section{Excerpt 4}

When I use target language exclusively to conduct my presentations, I see in their [students'] eyes that they didn't get it and that's when I switch to Turkish. I have to. Part of it is the policies and part of it is the learner profile. For instance by the third quarter, we start at B1, but the students are not up to the level. So they are already feeling beaten down, and me using target language exclusively only makes matters worse. If I use target language exclusively, I'll lose more than half of the class. They are already thinking they are going to fail, and are only coming so as not to fail due to absenteeism. So I do what I need to do, and code switch. When this happens, the ones who don't understand Turkish are left behind, but there isn't much I can do.

The state of the classrooms as they are described, and the extract above presents a striking contrast to the responses to the items 1 (planning diversity promoting activities), 2 (understanding on the various communication styles employed by diverse groups) and 13 (integrating values and lifestyles of diverse students into teaching practices) on the MTCS. The positive response rate to the said items on the MTCS are $85.5 \%$ for planning diversity-promoting activities, $98 \%$ for understanding various communication styles employed by diverse groups and $95.6 \%$ for integrating the values of diverse groups into the classroom practices. Since the participants have all stressed there is a difference between the ideal and the actual classroom practices, it can be concluded that the instructors responded to the MTCS were responding with ideals in mind rather than reflecting their actual practices. Another way of describing the situation could be evoking the presence of a social desirability bias, which is described as the tendency of research subjects to give socially desirable responses instead of choosing responses that are reflective of their true feelings (Grimm, 2010).

It is also important to note that none of the interview participants have detailed how they conduct their classes other than ambiguous remarks on the medium of instruction and the general atmosphere of the classroom. Regarding activities that promote diversity, culturally responsive pedagogy, affirming strategies or integration of cultural values, all interview participants refrained from providing details. Nonetheless, given $75 \%$ was evidenced not to have received any sort of formal training on multicultural education, expecting them to cater to the needs of diverse groups without any training is not realistic at best. In addition to presenting a serious discrepancy between the espoused theories the participants have and their practices, the findings also highlight the salience and urgency of explicit training about cultural diversity in meeting the educational needs of linguistically and culturally diverse students.

\subsubsection{Curriculum and material modification}

To reiterate, $60.5 \%$ of the instructors for scale item 8 , integration of diversity in the curriculum and $66.7 \%$ of them for scale item 12, examination of lesson material for biases, gave responses as either slightly, moderately or strongly agree. To support these findings, the interview participants were asked to describe the issue of adapting their teaching materials (Interview question: Have you ever needed to adapt or modify your material due to the multicultural and multilingual setting of your classes? If yes, why/how? If no, why not?). To the question on the material adaptation/modification, some instructors participating in the interviews and some others responding to the scale (on the comments section of the scale form) said that either they don't feel a need to adapt their material as they perceive those to be multicultural already, or adapting the material is simply not in their hands. 
Two of the instructors stated that they are expected to follow a centralized syllabus, and the testing offices of their respective schools are working with the syllabus designers. Thus, with any change they make, they risk either lagging behind or exposing their students to uncovered material during the tests.

However, Ayşe stated that most of the textbooks are oriented towards British or American culture norms, and she needs to integrate the cultures of her students into classroom practices, even though she also needs to follow a centralized syllabus. Thus, her way of modifying material is not by means of subtracting material, but adding what she perceives as proper.

\subsubsection{The effect of the learner's and teacher's own cultural background on instruction}

In line with the MTCS item 7, which asks the participants to self-report their knowledge about racial and ethnic identity theories, the interviewees were asked to state their opinions on the effect of the learner's and the teacher's own cultural background on the instruction (Interview questions: Do you think the educational issues are dependent on the cultural and linguistic background of the learner? If yes, could you elaborate? Do you think the learner's cultural and linguistic identity plays a role in their language learning process? If so, how? and Do you think your own cultural background has an effect on your teaching?) Reflecting the findings obtained from the MTCS, five out of six respondents affirm that the learner's cultural background (i.e. past experiences, values, beliefs) to have an effect on language learning, and the teacher's cultural background affects his/her teaching.

Ayşe notes that "we add on our existing values and perceive the input with our own cultural perspective." However, Cansu states that she is not sure how it works even though she is aware that "the learners feel motivated when they find a piece of their culture in the language learning materials used." Betül, on the other hand, states that she does not think the culture of the learner, or her own culture, to play a role, though she also states that the effect of the mother tongue is clear on the language learning process of the learner.

\subsubsection{Instructor's Role in Promoting Diversity}

When the participants asked about the role of diversity in foreign language instruction (Interview question: Do you promote cultural and linguistic diversity in your classrooms? If so, why/how? If no, why not?) In line with scale items 10 (making changes in the school environment to provide equal opportunity for diverse students) and 15 (teacher promoting diversity by her behaviour), two themes emerged. While half of the participants believe English to be a lingua franca that best develops when utilized in real communication, which diverse classrooms enable; the other half states the diversity in a language classroom is a tool for building dialogue between cultures as it helps students to be more embracing of difference rather than being hostile as they share an intense experience together (Fatma). Fatma also notes that she never witnessed a student from a diverse class speak ill of their classmates no matter what the political zeitgeist is as the shared experience helps the student body to become more empathetic.

Though admitting not making changes in the school environment to integrate diverse students because it is not in their hands (Deniz), all participants, barring Betül, reported that they encourage minority students as well as the majority groups to bring in their own experiences and perspectives in the class since it aids in enriching the students worldview. Deniz, for example said

\section{Excerpt 5}

I encourage my students to speak up in class, and nudging them into sharing their point of view is my way of personalizing the class to the needs of the students. They talk about their own experiences and how they feel about it. Listening to their peers presenting a different perspective helps the students grasp there is more than one dimension to any issue, and I'd like to believe it enriches their worldview. 


\subsubsection{Instructors' perception of multicultural and multilingual classrooms}

When the participants were asked to define the issues that they face in their multicultural and multilingual classes (Interview question: Do you ever have issues because you have a student/students from diverse cultures and languages in your classroom? If yes, could you elaborate?), they identified the use of their native language [Turkish] as the primary source of issues, as it causes the minority students feel "uncomfortable, alienated, and excluded".

The other issues identified were the bias or the focus of the material utilized in its reflecting Western cultural norms, cultural issues such as gender politics of certain cultures and its echoes in the classroom context, and native language related issues such as the spelling or syntax related problems the speakers of non-Latin alphabet using languages. Betül, for example, said

Excerpt 6

If students, for instance, come from conservative countries, they have some problems related to gender issues. Like grouping male and female students in class or in group work. Also if they don't use Latin alphabet for their mother tongue, students from these countries have common problems in writing.

Despite voicing their concerns regarding potential for (a) culture clash and misunderstandings, and (b) teacher readiness related issues such as classroom management problems and instructors' inadequacy in multicultural skill, the participants were found to be generally optimistic and accommodating of diverse classrooms, as it leads to (a) cultural exchange and variety, (b) helps building a tolerant atmosphere and higher intercultural awareness, and creates a classroom setting where the learners are more motivated and more communicative. The following remarks illustrate the positive attitude of two instructors:

\section{Excerpt 7}

Being in a multicultural and multilingual classroom setting teaches everyone to be tolerant of other cultures, and it shows there are numerous ways of doing a similar thing and it is completely okay. It is just a matter of perspective. There is no rights or wrongs in perspectives. On the contrary, it contributes to cultural richness which is a big part of English language they wish to learn.

\section{Excerpt 8}

The students, Turkish ones, are very curious of otherness, so the presence of others in the class lead to more production, to more interaction. Maybe it's just my class but I feel like it is a good addition.

\section{Conclusion}

As mentioned above, this study was conducted to find answers to the following research questions.

1. What is the perception of Turkish EFL instructors regarding their readiness to teach learners from diverse cultural and linguistic backgrounds?

2. How do the instructors assess their multicultural competence with specific reference to their multicultural knowledge and multicultural skills?

Based on the findings, the first question regarding the perception of the instructors can be answered in a multi-layered way. When inquired about their perception on diverse classrooms, it was seen that the participants generally hold a positive attitude towards diversity, as it leads to a richer classroom environment where the cultural exchange helps building tolerance, and raises the awareness of both learners and the instructors. As an added benefit, the instructors reported that the opportunities for increased interaction in diverse classrooms aids language production, which leads to more communicative classroom contexts. 
However, the participants are also wary of some aspects of diverse classroom contexts, as they fear a culture clash between majority and minority groups, which can stem from misunderstandings. Also, it can be said the instructors do not deem themselves ready to face the challenges posed by these contexts, as they confirm they are not trained to deal with multicultural settings. If the instructors are not informed about the culture and the language of the minority groups in the class, they may not be able to establish a much needed connection with the diverse students, which might lead to dwindling motivation. (Pintrich, 2003)

The classroom management issues aside, the medium of instruction is the biggest issue that the participants articulated. As stated several times during the interviews, the instructors feel compelled to utilize their and the majority of the learners' native language, Turkish, during instruction. While the reasons for such choice vary, and beyond the scope of this study, heavy use of Turkish in the class causes the minority students to feel excluded. On several occasions, minority students were described as quiet and, in one occasion, as explosive. Regarding the salience of bilingualism and multilingualism in the classroom, van Lier (2008) stresses the need for an interrelationship between the teacher and the learners since the engagement of the teacher with the learners helps the emergence of new identity positions associated with language learning process. Taking the argument upside down, it can be said a monolingual setting where the students from diverse settings and their languages are ignored may result in quiet and uninterested students who do not feel they belong in.

As for the question of self-assessment of instructors, a comparison of the scale results with those acquired through the interviews presents an interesting discrepancy. While the participants of the interview deem themselves not equipped to face the challenges presented by multicultural and multilingual classroom settings as they did not receive any formal training on the issue, the responses to the statements of the MTCS accumulate on the positive end of the scale. The average of the positive responses (4- slightly agree, 5- moderately agree, 6- strongly agree) to multicultural skill portion of the scale is $73.01 \%$ and it is $74.3 \%$ for the multicultural knowledge portion of the scale, implying that the participants deem themselves competent in their multicultural skill and knowledge. Clearly, the tendency is to give a positive answer, but the participants are not confident enough to give an assertive, strong positive. Thus, it can be argued the instructors participating in the MTCS replied with a social desirability bias even when they were unsure. This seems to be in line with the admittance of the scale developers when they state the scale demonstrates adequate internal consistency while noting they did not include any elements to weed out the social desirability bias (Spaniermen et. al., 2011). The following excerpt is salient in terms of presenting how one instructor feels about this:

\section{Excerpt 9}

"When I reflect on the issue of multicultural classes, I feel like I know nothing and I made a lot of mistakes along the way. I was not aware, and I have been doing what I always do but when I reflected [upon the questions] I realized how little I knew. For instance I never thought of modifying my material for potential cultural bias....

This study is not without limitations. One major limitation of this study is the sample size with 48 participants on the scale portion and five participants during the interviews. Though the collected data provide us with some insights, the representation is not enough to come to more generalized conclusions. Another limitation is the lack of classroom observations that would serve to verify the self-reporting of the participants. As Rosenman, Tennekoon and Hill (2011) notes self-reporting can be problematic due to the intervention of various biases. Thus, it would provide more illuminating results if the quantitative and qualitative data were supported by observations in further studies.

In spite of limitations, the study calls for an urgent need for the preparation of the instructors to tackle challenges posed by teaching in diverse classrooms. Smith (2009) asserts the success or failure of 
multicultural education depends on the effective preparation of teachers and administrators. When the teachers and administrators understand the learning needs of students and recognize how these needs can be different than the needs of the students from the dominant culture, and then the actual learning occurs.

Gay $(2000,2002)$ adds to this by stating that the teachers of diverse classes need to be explicitly trained on culturally responsive teaching which covers ethnic identity theories, communication styles of different ethnic and racial groups, potential curriculum (and thus material) biases and cross-cultural communication methods. Paradoxically, this study showed that an overwhelming majority of the EFL instructors participating in the study was not trained to meet the potential challenges they might encounter in the classrooms including learners from diverse linguistic and cultural backgrounds. When the fact that Turkey was not -historically - an immigrant destination (Baban \&Rygiel, 2018), training multiculturally competent teachers was a non-issue; thus it was often overlooked. However, Turkey is now a destination country since it hosts 3.6 million registered Syrians and 365,000 persons of concern from other nationalities (UNHCR) as of 2019. The changing circumstances make it urgent to aid the workforce and train the up and coming generations since the repercussions of ignoring a body of learners at this size can tax both the native and the immigrant societies.

The comments that the instructors left at the end of the scale and their remarks in the interviews suggest that the instructors are open to change, and are trying their best to better the learning experience for all their students, though they have not been supported with much needed training. Given the current state of the affairs in the Turkish context, if the goal is to prevent "a lost generation" of immigrant youth (Kirişçi, 2014), we simply cannot wait any longer or leave educators to their own devices.

\section{References}

Baban, F., \& Rygiel, K. (2018). Birlikte Yaşamak: Kültürel Çoğulculuğu Sanat Yoluyla Geliştirmek. İstanbul Kültür Sanat Vakfi.

Banks, J. A., \& Banks, C. A. M. (2001). Multicultural Education: Issues And Perspectives. (4th ed.) John Wiley.

Banks, J. A. (1993). Multicultural education: Historical development, dimensions and practice. Review of Research in Education. Vol. 19, pp. 3-49

Bergeron, B. S. (2008). Enacting a culturally responsive curriculum in a novice teacher's classroom: Encountering disequilibrium. Urban Education, 43, 4-28.

Chavez, A. F., \& Guido-DiBrito, F. (1999). Racial and ethnic identity and development. New Directions for Adult and Continuing Education, No 84. 39-46.

Chein, I. ( 1981 ). Appendix: An introduction to sampling. In L. H. Kidder (Ed.), Selltiz, Wrightsman \& Cook's research methods in social relations. (4th ed. ) (p. 418 -441). Austin, TX : Holt, Rinehart and Winston .

Çokluk, Ö., Şekercioğlu, G., \& Büyüköztürk, Ş. (2014). Sosyal bilimler için çok değişkenli istatistik: SPSS ve LISREL uygulamalart. Pegem Akademi

Erikson, E. (1968). Identity: Youth and Crisis. New York: Norton.

Fraenkel, J. R., Wallen, N. E., \& Hyun, H. H. (2012). How to Design and Evaluate Research in Education (8th ed.). New York: Mc Graw Hill. 
Gay, G. (2000). Culturally responsive teaching: Theory, Research and Practice. New York: Teachers College Press

Gay, G. (2002). Preparing for culturally responsive teaching. Journal of Teacher Education, Vol. 53, No. 2, pp. 106-116

Grimm, P. (2010). Social Desirability Bias. Wiley International Encyclopedia of Marketing.

Johnson, R. B., \& Onwuegbuzie, A. J. (2004). Mixed methods research: A research paradigm whose time has come. Educational Researcher. Vol: 33, Issue: 7, pp. 14 - 26

Kirişçi, K. (2014). Syrian Refugees and Turkey's Challenges: Going Beyond Hospitality, Washington: Brookings

Lynch, M. (2011). What is culturally responsive pedagogy? Blog Entry, Retrieved From: https://www.huffingtonpost.com/matthew-lynch-edd/culturally-responsivepedagogy b 1147364.html

Matsumoto, D., \& Juang, L. (2007). Culture and Psychology. Belmont, CA: Wadsworth Publishing Co Inc.

Miles, M. B., \& Huberman, A. M. (1994). Qualitative Data Analysis: An Expanded Sourcebook. (2nd Edition). California: SAGE Publications.

Modood, T. (2015). Multiculturalism. The Wiley Blackwell Encyclopedia of Race, Ethnicity, and Nationalism. 1-6.

Nieto, S. (2000). Affirming Diversity: The Sociopolitical Context of Multicultural Education (3rd ed.). New York: Longman.

Oxford Dictionaries, Multiculturalism definition. Retrieved on: March, 2018. https://en.oxforddictionaries.com/definition/multiculturalism

Parekh, B. (2006). Rethinking Multiculturalism: Cultural Diversity and Political Theory (2 ${ }^{\text {nd }}$ ed.) Palgrave: Macmillan.

Patton, M. Q. (2002). Qualitative Research \& Evaluation Methods. SAGE Publishing.

Phinney, J. S., \& Alipuria, L. L. (1987). Ethnic Identity In Older Adolescents From Four Ethnic Groups. Paper presented at the Biennial Meeting of the Society for Research in Child Development, Baltimore: USA.

Pintrich, P. R. (2003). A Motivational Science Perspective on the Role of Student Motivation in Learning and Teaching Contexts. Journal of Educational Psychology by the American Psychological Association, Inc. Vol. 95, No. 4, 667-686

Quintana, S., M. (2007). Racial and ethnic identity: Developmental perspectives and research. Journal of Counseling Psychology. Vol 54, No 3, 259-270.

Rosenman, R., Tennekoon, V., \& Hill, L.G. (2011). Measuring bias in self-reported data. International Journal of Behavioral and Healthcare Research, Vol. 2, No. 4/2011, pp. 320-332.

Smith, E. B. (2009). Approaches to multicultural education in pre-service teacher education: philosophical frameworks and models for Teaching. Multicultural Education. Vol. 16. No. 3. Pp. 4550 Available on: https://eric.ed.gov/?id=EJ847145

Spanierman, L.B., Oh, E., Heppner, P.P., Neville, H.A., Mobley, M., Wright, C.V., Dillon, F.R., \& Navarro, R. (2011). The Multicultural teaching competency scale: Development and initial validation. Urban Education. 46(3) 440-464

The UN Refugee Agency, UNHCR. Figures at a glance. http://www.unhcr.org/figures-at-a-glance.html (Retrieved on August, 2019) 
The Universal Declaration of Human Rights, (1948). Article 26. http://www.un.org/en/universaldeclaration-human-rights/ (Retrieved on March, 2018)

Turkish Ministry of Interior Directorate General of Migration Management. (2019). Migration statistics, Retrieved from: https://www.goc.gov.tr/gecici-koruma5638

UNESCO Universal Declaration on Cultural Diversity (2001). Retrieved from: http://portal.unesco.org/en/ev.php.URL ID=13179\&URL DO=DO TOPIC\&URL_SECTION=201.html

van Lier, L. (2008). The ecology of language learning and sociocultural theory. In Creese. A., Martin. P. and Hornberger N. H. (Eds.), Encyclopedia of language and education: Vol. 9. Ecology of language (2nd ed., p. 53-65). Boston: Springer Science+Business Media

\section{Kültürel ve dilsel olarak farklı sınıflarda öğretim: Türkiye'de yabancı dil olarak İngilizce öğreten öğretim elemanlarının deneyimi}

\section{$\ddot{O} \mathbf{z}$}

Bu çalışma, Türkiye'deki yabancı dil olarak İngilizce öğreten öğretim elemanlarının farklı kültür ve dil geçmişlerinden gelen öğrencilerin olduğu sınıflarda öğretim yapma hazırbulunuşluklarını ve yaşadıkları sorunları incelemeyi amaçlamaktadır. Hem nitel hem de nicel veri toplama araçlarının kullanıldığı çalışmada, Çokkültürlü Öğretim Yeterlilik Ölçeği (MTCS) (Spanierman et. al., 2011) ve yarı-yapılandırılmış görüşmeler aracılı̆̆ıyla veri toplanmıştır. Ölçekten elde edilen bulgular, katılımcı öğretim elemanlarının çokkültürlülük bilgi ve becerisi bakımından kendilerini yetkin bulduklarını ortaya koyarken, görüşmelerden elde edilen nitel veri katılımcıların gerekli eğitimleri almamış olmaları sebebiyle farklı dil ve kültür geçmişinden gelen öğrencilerin akademik ve dil öğretimi ile ilgili ihtiyaçlarını karşılamak konusunda kendilerini yetersiz hissettiklerini ortaya koymuştur. Bu çalışma, öğretim elemanlarının çokkültürlü ve çokdilli sınıflarda etkili ve verimli çalışabilmeleri için gerekli farkındalık, bilgi ve becerilerin arttııımasına yönelik eğitim programlarının ivedilikle geliştirilmesi ve uygulanması gerekliliğini ortaya koymuştur.

Anahtar sözcükler: Çok kültürlü eğitim; öğretmen yeterliliği; çok kültürlü öğretim yeterlilik ölçeği; yabancı dil öğretimi; yabancı dil olarak İngilizce

\section{AUTHOR BIODATA}

Rana Yıldırım holds an MA from Cukurova University and an MSc and a PhD in teaching English as a Foreign Language from Aston University, United Kingdom. She has been working as an associate professor in the ELT Department of Çukurova University, Turkey. Her research interests include pre- and in-service language teacher education, teaching English to young learners, teaching in diverse contexts and gifted language learners. 